\title{
Home Purchase Decision Support System Using the Brown- Gibson Method
}

\author{
Rita Frances \\ Faculty of Science and Technology, Universitas Sanata Dharma, Indonesia
}

\begin{tabular}{|c|c|}
\hline ARTICLEINFO & ABSTRACT \\
\hline Article history: & Thesis. The application program was built by applying the Brown- \\
\hline $\begin{array}{r}\text { Received Dec 28, } 2020 \\
\text { Revised Jan 08, } 2021 \\
\text { Accepted Jan 20, } 2021\end{array}$ & $\begin{array}{l}\text { Gibson method which is capable of measuring both qualitative and } \\
\text { In making a decision to buy a house, a buyer will consider a variety } \\
\text { of complex criteria, such as qualitative (non-numeric) and } \\
\text { quantitative (numeric) criteria to get the best decision. To simplify the }\end{array}$ \\
\hline $\begin{array}{r}\text { Keywords: } \\
\text { Brown-Gibson; } \\
\text { Decision Support System; } \\
\text { House. }\end{array}$ & $\begin{array}{l}\text { created in this quantitative criteria. The algorithms in the Brown- } \\
\text { Gibson method used in this application program include: } \\
\text { "Performance Measurement" to measure quantitative criteria, such } \\
\text { as house selling price, land area, building area and number of } \\
\text { bedrooms; "Pairwise Comparison" to measure qualitative criteria, } \\
\text { such as architectural style, position of the building, proximity to the } \\
\text { work environment, proximity to shopping centers, proximity to the } \\
\text { educational environment, state of the home environment, building } \\
\text { status, house certificate; and "Preference of Measurement" which } \\
\text { combines the quantitative and qualitative criteria to produce a priority } \\
\text { weight that can be accepted as a measurement result for each } \\
\text { alternative house as a whole. The final result of this thesis is an } \\
\text { application program that provides the highest value for an alternative } \\
\text { home. The house that gets the highest score is an alternative house } \\
\text { that has the most suitable specifications according to the criteria } \\
\text { considered by the buyer. The house that gets the highest score is an } \\
\text { alternative house that has the most suitable specifications according } \\
\text { to the criteria considered by the buyer. the condition of the house } \\
\text { environment, the status of the building, the certificate of the house; } \\
\text { and "Preference of Measurement" which combines the quantitative } \\
\text { and qualitative criteria to produce a priority weight that can be } \\
\text { accepted as a measurement result for each alternative house as a } \\
\text { whole. The final result of this thesis is an application program that } \\
\text { provides the highest value for an alternative home. The house that } \\
\text { gets the highest score is an alternative house that has the most } \\
\text { suitable specifications according to the criteria considered by the } \\
\text { buyer. and "Preference of Measurement" which combines the } \\
\text { quantitative and qualitative criteria to produce a priority weight that } \\
\text { can be accepted as a measurement result for each alternative house } \\
\text { as a whole. }\end{array}$ \\
\hline
\end{tabular}

This is an open access article under the CC BY-NC license.

\section{Corresponding Author:}

Rita Frances

Faculty of Science and Technology, Universitas Sanata Dharma, Indonesia

E-mail: ritafrances01gmail.com 


\section{INTRODUCTION}

The ability to make quick and careful decisions will be the key to success in global competition in the future. Having a lot of information alone is not enough if you are not able to process it quickly into the best alternatives in decision making.

In general, a decision is made in order to solve a problem (problem solving), every decision made must have a goal to be achieved. Just as a home buyer decides the type of housing and the desired housing location in order to meet the goals he wants to achieve. Making a decision means choosing the best alternative among many alternatives. Decisions are made by almost everyone, either individually or on their own behalf, by the leadership of an organization or company and so on. "Choosing Housing" is an example of an individual problem where each individual has the right to choose more than 2 desired housing alternatives, and various criteria are set by each individual. The many and complex criteria in choosing housing where it takes a quick time to decide can cause problems if a system that supports decision making is not made. The system is a "DecisionMaking Support System". The criteria that are used as references come from companies such as house prices, location, type of property, home environment, educational environment, learning environment and so on. Because of these criteria, a decision support system was determined using the Brown-Gibson method.

The Brown-Gibson method is basically similar to the product positioning method or the method of determining the location of a place. The advantage of this method lies in the calculation of the two factors, namely the objective factor and the subjective factor. In using this method, the calculation is based on objective factors, which are related to a value or measure, and subjective factors, in which there is a comparison of criteria that have no numerical size. The use of this method will be able to determine the best housing and best suit the wishes of home buyers.

\section{METHOD}

The method used to design a web-based support system for taking Labuan Bajo tour packages is done by:

1. Preparation

What is meant by this preparation is that it begins with the preparation of proposals and administering permits in research.

2. Data collection

In data collection consists of:

a. Direct consultation with parties who are experts in the field, in this case the supervisors, parties from the tourism and culture office of Labuan Bajo, and also parties involved in this system.

b. Observations were made by making direct observations with existing physical situations and conditions.

c. Literature study to obtain existing literature, in the form of books, internet media and references related to this title.

3. Analysis

The analysis phase carried out is an analysis of the main problems faced. In this stage will produce a cause-and-effect analysis. The stage of collecting data on system requirements and analyzing it, data collection carried out includes interviews, observations and literature studies.

\section{RESULTS AND DISCUSSIONS}

\subsection{Brown-Gibson Algorithm Analysis}

Analysis of the house selection process using the Brown-Gibson method. In analyzing the Brown-Gibson application, sample data obtained from the survey results of the Era Master property company, the results of interviews with the Marketing Era Master property company, and the results of interviews with several home buyers are used:

a. Property Type Data 
Table 1.

Property Type Data Table

\begin{tabular}{rc}
\hline Property Type Code & Property Type \\
\hline TP01 & House \\
TP02 & Shop \\
TP03 & Rukan \\
\hline
\end{tabular}

b. Region Data

Table 2.

Region Data Table

\begin{tabular}{cc}
\hline Area code & Region \\
\hline W0001 & North Yogyakarta \\
W0002 & South Yogyakarta \\
W003 & West Yogyakarta \\
W0004 & East Yogyakarta \\
W0005 & Central Yogyakarta \\
\hline
\end{tabular}

c. Location Data

Table 3.

Location Data Table

\begin{tabular}{|c|c|}
\hline Location Code & Location \\
\hline L0001 & Godean \\
\hline L0002 & Single Chess Depok Sleman \\
\hline L0003 & Chess Lean \\
\hline L0004 & Maguwoharjo \\
\hline L0005 & Pakualaman \\
\hline L0006 & Mantrijeron \\
\hline L0007 0008 & Settings \\
\hline L0009 & Sengkan Sleman \\
\hline
\end{tabular}

d. Housing Data

Table 4.

Housing Data Table

\begin{tabular}{cl}
\hline House Selling Price & \multicolumn{1}{c}{ Facility } \\
\hline IDR 975,000,000.00 & 1 garage, 2200 Watts of electricity, 1 telephone, well \\
IDR 700,000,000.00 & 1 maid room, 1 main room, 1 garage, 2200 Watts electricity, 2 floors, well, WTP \\
Rp.850,000,000.00 & 1 bathroom, 2 floors, 1 maid's room, 2200 Watts of electricity, well, WTP \\
IDR 675,000,000.00 & 2 bathrooms, 1 maid's room, 1 master bedroom, 1300 Watts of electricity, 1 \\
IDR 550,000,000.00 & garage, well, 2 floors \\
IDR 475,000,000.00 & 1 bathroom, 1 floor, 1 master bedroom, 1300 Watts electricity, well \\
Rp.750,000,000.00 & 2200 Watts electricity, 4 Split AC, 2 telephones \\
IDR 425,000,000.00 & 3500 Watts electricity, 1 telephone \\
\hline
\end{tabular}

e. Numerical Criteria Data

Table 5.

Numerical Criteria Data Table

\begin{tabular}{cc}
\hline Criteria Code & Criteria Name \\
\hline N01 & House Selling Price \\
N02 & Building area \\
N03 & Surface area \\
N04 & Bedroom \\
\hline
\end{tabular}

f. Non-Numeric Criteria Data 
Table 6.

Non-Numeric Criteria Data Table

\begin{tabular}{cc}
\hline Criteria Code & Criteria Name \\
\hline NN01 & Architectural Style \\
NN02 & Building Position \\
NN03 & Proximity to Shopping Neighborhood \\
NN04 & Proximity to the Work Environment \\
NN05 & Proximity to the Educational Environment \\
NN06 & Home Environment Keadaan \\
NN07 & Home Status Type \\
NN08 & Certificate Type \\
\hline
\end{tabular}

From the data above, home buyers are looking for houses located in the Condong Catur location and the numerical criteria chosen are the Selling Price of the House and Land Area, while the non-numeric criteria selected are Architectural Style, Proximity to the Educational Environment, and Condition of the Home Environment.

From the criteria chosen by home buyers, the numerical criteria chosen are the selling price of the house and the area of land. For the numerical criteria for the selling price of the house, buyers prioritize houses with good building conditions. For the numerical criteria for land area, buyers prioritize houses with a land area of less than $150 \mathrm{~m} 2$. Then the calculation process for the numerical criteria / objective factors is:

Table 7.

House Selling Price Factor (1)

\begin{tabular}{ccccc}
\hline Alternative & Selling price & Condition & Total & $1 / \mathrm{Ci}$ \\
Selected House & House & Building & Si) & 3.3333 \\
\hline 00013 (Alternative A) & $475,000,000,000$ & Standard & 0.3 & 5 \\
00014 (Alternative B) & $750,000,000,000$ & Good & 0.2 & 10 \\
00015(Alternative C) & $425,000,000,000$ & Good & 0.1 & 18.3333
\end{tabular}

The value of the Price Per m2 (1) factor for each alternative house is:

$\mathrm{OFij}=\left[\mathrm{Ci}^{*}(1 / \mathrm{Ci})\right] 1$, whereas OFij $=1$

$$
\begin{array}{r}
\mathrm{OF}(\mathrm{A} 1)=\left[(0,3){ }^{*}(18,3333)\right] 1=[5,4999] 1=0.1818 \\
\mathrm{OF}(\mathrm{B} 1)=[(0,2) *(18,333)] 1=[3.6666] 1=0.2727 \\
\mathrm{OF}(\mathrm{c} 1)=[(0,1) *(18,3333)] 1=[1.8333] 1=0.5454+ \\
\operatorname{OF}(\mathrm{i} 1)=0.99991 .0000
\end{array}
$$

\begin{tabular}{|c|c|c|c|}
\hline $\begin{array}{l}\text { Home Alternative } \\
\text { Selected }\end{array}$ & $\begin{array}{c}\left.\text { (Hundreds of } \mathrm{m}^{2}\right) \\
\text { Surface area }\end{array}$ & Total $(\mathbf{C i})$ & $1 / \mathrm{Ci}$ \\
\hline 00013 (Alternative A) & 1.27 & 1.27 & 0.7874 \\
\hline 00014(Alternative B) & 1.76 & 1.76 & 0.5681 \\
\hline 00015(Alternative C) & 1.21 & 1.21 & 0.8264 \\
\hline & Totals & & 2.1819 \\
\hline
\end{tabular}

Table 8.

Objective Factors Land Area Factors (2)

The factor value of Land Area (1) for each alternative house is:

OFij $=\left[\mathrm{Ci}^{*}(1 / \mathrm{Ci})\right] 1$, whereas OFij $=1$

$\mathrm{OF}(\mathrm{A} 2)=[(1.27) *(2.1819)] 1=[2.7710) 1=0.3608$

$\mathrm{OF}(\mathrm{B} 2)=[(1.76) *(2.1819)] 1=[3.8401] 1=0.2604$

$\mathrm{OF}(\mathrm{C} 2)=[(1.21) *(2.1819)] 1=[2,6400] 1=0.3787+$

$\mathrm{OF}(\mathrm{i} 2)=0.99991 .0000$ 
Based on this data, the objective factors for each alternative house can be searched with the following formula:

\section{$\mathrm{OFi}=\left[\mathrm{Ci}{ }^{*}(1 / \mathrm{Ci})\right] 1$, whereas $\mathrm{OFi}=1$}

Meanwhile, the non-numeric criteria/subjective factors selected were Architectural Style, Proximity to the Educational Environment, and the State of the Home Environment. Then home buyers are asked to give an assessment of the subjective factors that have been selected in pairs, and the results are for example as follows:

1. Architectural Style (1) $x$ Proximity to the Educational Environment (2); Here Proximity to the Educational Environment is considered more important to consider than Architectural Style.

2. Architectural Style (1) $\times$ State of the Home Environment (3); In this case, the State of the Home Environment is considered more important to consider than the Architectural Style.

3. Proximity to the Educational Environment (2) x Condition of the Home Environment (3); Here Proximity to the Educational Environment is considered more important to consider than the State of the Home Environment.

From the information above, it can be concluded that the Subjective-factor Importance Index (wj), namely:

Table 9.

Objective Factors Land Area Factors (2)

\begin{tabular}{lccccc}
\hline \multicolumn{1}{c}{ Subjective Factor } & \multicolumn{3}{c}{ Pariwise Comparison } & $\begin{array}{c}\text { Number of } \\
\text { Preferences }\end{array}$ & $\begin{array}{c}\text { Relative } \\
\text { portance Index (wj) }\end{array}$ \\
\cline { 2 - 5 } & 1 & 2 & 3 & 0 & $0 / 3=0.0000$ \\
Architectural Style (1) & 0 & 0 & & 2 & $2 / 3=0.6666$ \\
$\begin{array}{l}\text { Proximity to the Environment } \\
\text { Education (2) }\end{array}$ & 1 & & 1 & 1 & $1 / 3=0.3333$ \\
Home Environment (3) & & 1 & 0 & 3 & $=0.9999$ \\
& & & Totals : & & $=1.0000$ \\
\hline
\end{tabular}

In the assessment, a point of 1 will be given to the factor that is considered more important while the one that is considered less important is scored with 0 . In cases where the pair being compared turns out to be equally important, each factor is scored equal to 1 Furthermore, with the same procedure, separately evaluate each alternative house to obtain a ranking (Rij). For the selected alternative houses, the following conclusions are drawn:

Table 10.

Comparison of Choice House Alternatives based on Architectural Style Factors (1)

\begin{tabular}{cccccccc}
\hline \multirow{2}{*}{ Home Alternative } & \multicolumn{9}{c}{ Pariwise Comparison } & \multirow{2}{*}{ Number of Preferences } & \multirow{2}{*}{ Rank (Rij) } \\
\cline { 2 - 5 } & 1 & 2 & 3 & 1 & $1 / 3=0.3333$ \\
A & 1 & 0 & & 0 & $0 / 3=0.0000$ \\
B & 0 & & 0 & 2 & $2 / 3=0.6666$ \\
C & & 1 & 1 & 3 & $=0.9999$ \\
& Totals : & & & & \\
\hline
\end{tabular}

Table 11.

Evaluation of Subjective Factors

\begin{tabular}{ccccc}
\hline Subjective Factor & \multicolumn{3}{c}{$\begin{array}{c}\text { Pariwise Comparison } \\
\text { (Alternative) }\end{array}$} \\
\cline { 2 - 4 } & $\mathrm{A}$ & $\mathrm{B}$ & $\mathrm{C}$ \\
\cline { 2 - 4 } & 0.3333 & 0.0000 & 0.6666 & 0.0000 \\
2 & 0.0000 & 0.5000 & 0.5000 & 0.6666 \\
3 & 0.6666 & 0.0000 & 0.3333 & 0.3333 \\
& & & Totals : & 0.9999 \\
& & & & 1.0000 \\
\hline
\end{tabular}

To determine the value of the subjective factor (SFi) for each alternative, it can be obtained by entering the data into the following formula:

$\mathrm{SFi}=\mathrm{wj}^{*} \mathrm{Rij}$, where $\sum \mathrm{SFi}=1$ 
$\mathrm{SFi}=w_{1} \mathrm{Pi}_{1} \omega_{2} \mathrm{Pl}_{2} \omega_{3} \mathrm{Pl}_{3} \square \omega_{n} \mathrm{P}_{n}$

So that the subjective factor values for each alternative house are:

$$
\begin{array}{lll}
\operatorname{SF}(A)=\left(0^{*} 0.3333\right)+\left(0.6666^{*} 0\right)+\left(0.3333^{*} 0.6666\right) & =0+0+0.2221 & =0.2221 \\
\mathrm{SF}(B)=\left(0^{*} 0\right)+\left(0.6666{ }^{*} 0.5\right)+\left(0.3333^{*} 0\right) & =0+0.3333+0 & =0.3333 \\
\mathrm{SF}(\mathrm{C})=\left(0^{*} 0.6666\right)+\left(0.6666^{*} 0.5\right)+\left(0.3333^{*} 0.3333\right)=0+0.3333+0.1110=0.4443
\end{array}
$$

\section{CONCLUSION}

The conclusion obtained from the creation and development of the Home Purchase Decision Support System application program is that the use of a computerized method in the Home Purchase Decision Support System can be an alternative method to serve home buyers at a property company because it can increase the efficiency of employees' working time, and able to improve the quality of good decisions and able to improve the quality of service to home buyers. The application of the Brown_Gibson method in making this system application program succeeded in obtaining an application program that could assist employees/marketing and home buyers in conducting the house selection process with complex criteria and factors in a property company. The use of the method of differentiating access rights for admin and marketing in making this program is able to maintain the security and accuracy of the data stored in the system database. The use of the search facility in this application program can increase time efficiency and save operational costs

\section{References}

Hartono, Jogiyanto, MBA, Ph. D., 1999, Analisis \& Disain, Yogyakarta: Andi Kasmoni, 2003, Visual Basic 6.0 untuk Orang Awam, Palembang: Maxikom

Kusumo, Ario Suryo, Drs., 2003, Pemograman Database dengan Visual Basic 6.0, Jakarta: Elex Media Komputindo

Malik, Jaja Jamaludin, 2007, Kumpulan Tip Trik Pemograman Visual Basic,

Yogyakarta: Andi

Nugroho, Bunafit, 2005, Visual Basic Membuat Animasi dan Tampilan Cantik pada Interface Form, Cetakan Pertama, Edisi Pertama, Yogyakarta: Gava Media

Polina, Agnes Maria S. Kom., M. Sc. \& Drs. Jong Jek Siang, M. Sc., 2005, Kiat Jitu Menyusun Skripsi Jurusan Informatika/Komputer, Yogyakarta: Andi

Sidik, Betha, Ir., April 2003, My SQL untuk Pengguna, Administrator dan Pengembang Aplikasi Web, Cetakan Pertama, Bandung: Informatika

Suja, Iman, 2005, Pemograman SQL dan Database Server MySQL, Yogyakarta: Andi

Turban, Efraim, Jay E. Aronson, Ting-Peng Liang, 2005, Decision Support Systems and Intelligent Systems (Sistem Pendukung Keputusan dan Sistem Cerdas), Jilid 1, Edisi 7, Yogyakarta: Andi

Whitten, Jeffrey L., Lonnie D. Bentley, Victor M. Barlow, 1994, Systems Analysis \& Design Methods, Third Edition, Illinois: Richard D. Irwin Inc.

Wignjosoebroto, Sritomo, 2003, Tata Letak Pabrik dan Pemindahan Bahan, Cetakan Ketiga, Edisi Ketiga, Surabaya: Guna Widy 